\title{
IDENTIFICATION OF THE FACTORS DETERMINING CORPORATE CAPITAL STRUCTURE IN THE CZECH REPUBLIC
}

\author{
[Identifikace faktorů determinujících kapitálovou strukturu firem v České \\ republice]
}

Lenka Strýčková ${ }^{1}$

\author{
${ }^{1}$ Technická univerzita v Liberci, Ekonomická fakulta, Studentská 1402/2,461 17Liberec 1 \\ Email:lenka.stryckova@tul.cz
}

\begin{abstract}
This study focuses on the identification of factors determining corporate capital structure in the Czech Republic, thereby contributing to an ongoing discussion on the capital structure determinants and the capital structure optimization. The paper aims to provide empirical evidence on the basis of the questionnaire survey. To identify the most significant factors affecting decisions of companies concerning their capital structure and debt policy, the statistical methods and procedures were used for the research evaluation. With the help of the factor analysis, the three key factors were derived: the financial aspects of debt financing, the debt as a tool of further development of the company, and the specifics debt and capital markets. The findings of this study moderately support conclusions of the trade-off theory, and the signalling theory. Furthermore, the survey results indicate that the firms in the Czech Republic start to perceive the capital markets as an integral part of the financial market and as a place for obtaining additional funding.
\end{abstract}

Keywords: capital structure, company, debt, determinants, equity, factors.

JEL classification: G32

Doručeno redakci: 25.5.2016; Recenzováno: 24.6.2016; 1.7.2016; Schváleno k publikování: 19.10.2016

\section{Úvod}

Každý podnik je jedinečný; má jiný př́stup ke zdrojům financování, svou podnikatelskou aktivitu vykonává v odlišném podnikatelském prostředí, může mít odlišné cíle. Podnik je ve svém rozhodování při výběru zdrojů financování ovlivněn jednak faktory, které jsou dány zevnitř podniku, jako je strategie, cíle a zaměření společnosti, vlastnická struktura, př́stup $\mathrm{k}$ riziku, obor podnikání a postavení podniku na daném trhu, unikátnost nabízené produkce a potenciál růstu, stáŕi podniku, hospodářské výsledky podniku apod. Volba zdrojů financování v podniku je zároveň determinováno i vnějším prostředím, které je tvořeno stupněm ekonomického rozvoje země, politickým prostředím, úrovní vyspělosti kapitálového trhu, monetární politikou státu, úrovní úrokových a daňových sazeb, príistupem státu $\mathrm{k}$ podpoře podnikání, platnou legislativou, úrovní konkurence v daném odvětví, mírou informační asymetrie a dalšími faktory.

Konkrétní podoba kapitálové struktury podniku je tedy v podstatě složitý proces závislý na velkém množství různých determinant a zvolená finanční strategie tedy závisí na rozhodnutí jednotlivých firem.

Cílem tohoto př́spěvku je identifikovat nejdůležitější faktory determinující kapitálovou strukturu firem v České republice na základě empirického dotazování. K identifikaci nejvýznamnějších faktorů byly použity statistické metody popisné statistiky a faktorové analýzy. 


\section{Teoretická východiska kapitálové struktury podniku}

Kapitálová struktura podniku je chápána jako vztah mezi vlastními a cizími zdroji, které podniky využívají pro financování své podnikatelské činnosti. Vztahem mezi vlastními a cizími zdroji podniku se již od počátku padesátých let minulého století zabývají různé teorie kapitálové struktury podniku. Zjednodušeně se teorie kapitálové struktury velkých společností dají shrnout do dvou základních skupin, na teorie statické a dynamické.

Dle statických teorií, mezi něž patří například kompromisní teorie, manažeři jednají v zájmu akcionářu. Z klasické teorie kapitálové struktury statické teorie přebírají „U“ křivku průměrných nákladů kapitálu. Za optimální je považována taková struktura kapitálu, kdy daňový štít co nejvíce převyšuje náklady finanční tísně (Titman, Wessels 1988). Statické teorie se tedy snaží najít optimální kapitálovou strukturu, zatímco dynamické teorie popírají existenci optimální kapitálové struktury. Dynamické teorie se na základě empirických výzkumů spíše snaží o vysvětlení chování a preferencí manažerů při rozhodování o zdrojích investic a stanovují určitou preferenční hierarchii finančních zdrojů podniku. Dle teorie hierarchického pořádku podniky jako první využijí interní vlastní zdroje (zisk), poté cizí zdroje a až jako poslední možnost externí vlastní kapitál (emitují akcie).

Jednou z dalších teorií kapitálové struktury podniku je teorie signalizování, kterou představil S. Ross ve své studii z roku 1977 (Ross 1977). Teorie signalizování je založená na existující informační asymetrii mezi manažery a investory. Předpokladem je, že manažeři mají všechny potřebné informace o hospodaření společnosti, zatímco externí investoři musí spoléhat pouze na zveřejňované informace. Proto pokud investoři vidí, že podnik zvyšuje svoji zadluženost, předpokládají, že se podnik nachází v dobré ekonomické situaci. Jiní autoři tuto teorii neuznávají a zpochybňují ji. Například M. Miller a K. Rock (1985) tvrdí naprostý opak. Uvádí, že zvyšování zadluženosti podniku není chápáno jako informace pozitivní, nýbrž negativní, protože si podnik nedostatečným hospodařením nevytvořil dostatečné prostředky $\mathrm{k}$ úhradě svých závazků.

Většina uznávaných teorií kapitálové struktury vznikala v anglosaském prostředí, proto tedy závěry těchto teorií nelze v českém prostředí aplikovat bez výhrad. Česká odborná literatura zabývající se problematikou kapitálové struktury podniku většinou přebírá závěry ze zahraničních publikací a zaměřuje se především na empirické ověřování platnosti těchto teorií v českém prostředí.

Zahraniční literatura, např. Baker (2011) uvádí tyto faktory ovlivňující kapitálovou strukturu: likvidita aktiv, velikost podniku, růstové příležitosti, ziskovost, volatilita, odvětví podnikání, vliv daní, úvěrový rating, situace na dluhovém trhu, situace na kapitálovém trhu a makroekonomické podmínky.

Tématem determinant kapitálové struktury se u nás zabývala např. Krauseová (1995). Krauseová provedla analýzu kapitálové struktury českých firem v závislosti na vnějším prostředí, především na historickém vývoji od roku 1989 a celoevropském období ekonomické recese. Ve své empirické studii dále analyzovala vlivy obratu majetku, ziskovosti, růstu, velikosti podniku a nestálosti (volatilitou) zisku na míru zadlužení dle odvětví podnikatelské činnosti. Zdůrazňuje konzervativnost podniků v př́stupu k zadlužování a v převažující akumulaci vlastního kapitálu. Poukazuje i na nízké využití emise dluhopisů jako kapitálového zdroje podniku. Předpokládá, že kapitálová struktura podniků se bude nadále vyvíjet ve prospěch navýšení cizího kapitálu. 
Tématem podnikových financí a kapitálové struktury se v českém prostředí zabývali i manželé Neumaierovi (1996). Teorie manželů Neumaierových potvrzuje kompromisní teorii a ve speciálních prŕípadech vychází z teorie F. Modiglianiho a K. H. Millera.

Kislingerová (2010) jako nejdůležitější faktory působící na rozhodování o míře zadluženosti uvádí velikost a stabilitu podnikového zisku, postavení podniku na trhu (tzv. provozní páka), stabilitu resp. volatilitu tržeb, majetkovou strukturu podniku (portfolio aktiv), finanční nezávislost podniku (finanční volnost), stabilitu rozdělování hospodářského výsledku.

Prášilová (2012) zkoumala, zda určité determinanty, konkrétně podíl fixních aktiv, zadržené zisky, úroková míra, rentabilita aktiv, velikost podniku, podíl hmotných aktiv a stáŕí podniku, mají vliv na kapitálovou strukturu a míru tohoto vlivu. Výsledkem její analýzy je zjištění, že na celkovou zadluženost podniků má pozitivní vliv stáří podniku a objem zadržených zisků a negativní vliv rentabilita aktiv a velikost podniku. Se svými závěry se přiklání $\mathrm{k}$ výsledkům průzkumů z posledních let, které uznávají částečný vliv obou hlavních teoretických př́stupů kompromisní teorie a teorie hierarchického pořádku na finanční rozhodování společností.

Aulová a Hlavsa (2013) se zabývali analýzou kapitálové struktury zemědělských podniků a jejích determinant. Zároveň ověřovali hypotézu, zda vliv jednotlivých determinant kapitálové struktury je v souladu s teoretickými předpoklady podmíněných teorií kapitálové struktury a empirickými studiemi. V souvislosti s tím provedli přehlednou kategorizaci vybraných determinant kapitálové struktury (velikost podniku, ziskovost, podíl hmotných aktiv na celkových aktivech, daňový štít, zadržené zisky a likvidita). U každé z těchto determinant byly identifikovány teoretické předpoklady vybraných teorií kapitálové struktury a zpracovány závěry různých empirických studií, které dokazují bud' pozitivní, nebo negativní vliv vybrané determinanty. $Z$ tohoto přehledu je jasně patrné, že obě fundamentální teorie kapitálové struktury se ve svých závěrech rozcházejí a že i jednotlivé empirické studie došly k rozdílným, často protichůdným, závěrům.

Růčková (2015) se zaměřuje na vliv dvou základních determinant, likvidity a rentability, na využití cizích zdrojů financování v podnicích zpracovatelského průmyslu v zemích Visegrádské čtyřky. Očekávaný pozitivní funkční vztah likvidity a rentability na větší využívání cizích zdrojů financování byl prokázán pouze u podniků z České republiky.

Dle Dvořáka (2004) kapitálový trh v České republice netvořil alternativní zdroj financování podniků. České společnosti vyplácí hotovostní dividendy akcionářů pouze v omezené míre, proto zdroje pro podnikatelskou činnost firmy získávají především z vnitřních zdrojů - např̀. zadržených zisků. Jedinou dostupnou alternativou jsou bankovní úvěry.

\section{Metodologie}

Při zpracování příspěvku byla nejprve použita metoda analýzy odborných tuzemských i zahraničních publikací a vědeckých statí, na základě níž byla pomocí syntézy získaných poznatků zpracována teoretická východiska. Studie dále obsahuje výsledky empirického šetření. Ke zpracování empirické části studie zaměřené na determinanty kapitálové struktury byla využita metoda faktorové analýzy. Jednotlivé determinanty, použité v dotazníkovém šetření, byly převzaty z dotazníku vytvořeného Grahamem a Harveyem (2001). Použití vybraných otázek z původního dotazníku bylo odsouhlaseno prof. Grahamem. Od zveřejnění dotazníku byl dotazník v nezměněné podobě použit $\mathrm{v}$ mnoha dalších empirických studiích v různých zemích světa pro mezinárodní srovnání, např. Bancel and Mittoo (2004), Brounen, de Jong and Koedijk (2004, 2006), Benetti, Decourt and Terra (2007). Dotazník je poměrně 
obsáhlý a obsahuje otázky z oblasti podnikových financí týkající se kapitálové struktury firem, nákladů na kapitál a kapitálového rozpočtování. Jednotlivé studie pak vyhodnocují výsledky dotazování ve vybrané zemi (či zemích), ověřují platnost vybraných teorií kapitálové struktury a provádí srovnání s ostatními zeměmi.

Tento př́spěvek využívá empirických výsledků dotazování provedeného na základě vybraných otázek z dotazníku Grahama a Harveye, jeho cílem však není srovnání s jinými zeměmi. Cílem příspěvku je za pomocí statistického vyhodnocení (faktorové analýzy) identifikovat dominantní determinanty kapitálové struktury podniků v České republice.

Tabulka 1: Skladba respondentů dotazníkového šetření

\begin{tabular}{|c|c|c|}
\hline & Počet respondentů & $\%$ \\
\hline \multicolumn{3}{|l|}{ Právní forma podnikání } \\
\hline Akciová společnost & 43 & $21,8 \%$ \\
\hline Společnost s ručením omezeným & 115 & $58,4 \%$ \\
\hline Jiná & 39 & $19,8 \%$ \\
\hline \multicolumn{3}{|l|}{ Počet pracovníků (velikost podniku) } \\
\hline 0-9 pracovníků (mikropodnik) & 60 & $30,5 \%$ \\
\hline 10-49 pracovníků (malý podnik) & 50 & $25,4 \%$ \\
\hline 50-249 pracovníkủ (střední podnik) & 44 & $22,3 \%$ \\
\hline 250 a více pracovníků (velký podnik) & 43 & $21,8 \%$ \\
\hline \multicolumn{3}{|l|}{ Obor podnikání dle CZ-NACE } \\
\hline C - Zpracovatelský průmysl & 58 & $29,4 \%$ \\
\hline $\begin{array}{l}\text { G - Velkoobchod a maloobchod; opravy a údržba } \\
\text { motorových vozidel }\end{array}$ & 46 & $23,4 \%$ \\
\hline M - Profesní, vědecké a technické činnosti & 20 & $10,2 \%$ \\
\hline N - Administrativní a podpůrné činnosti & 15 & $7,6 \%$ \\
\hline F - Stavebnictví & 14 & $7,1 \%$ \\
\hline A - Zemědělství, lesnictví a rybářství & 9 & $4,6 \%$ \\
\hline J - Peněžnictví a pojišt'ovnictví & 8 & $4,1 \%$ \\
\hline L - Činnosti v oblasti nemovitostí & 4 & $2,0 \%$ \\
\hline H - Doprava a skladování & 7 & $3,6 \%$ \\
\hline I - Ubytování, stravování a pohostinství & 7 & $3,6 \%$ \\
\hline $\begin{array}{l}\text { D - Výroba a rozvod elektřiny, plynu, tepla a } \\
\text { klimatizovaného vzduchu }\end{array}$ & 6 & $3,0 \%$ \\
\hline B - Těžba a dobývání & 2 & $1,0 \%$ \\
\hline $\begin{array}{l}\text { E - Zásobování vodou; činnosti související s } \\
\text { odpadními vodami, odpady a sanacemi }\end{array}$ & 1 & $0,5 \%$ \\
\hline \multicolumn{3}{|l|}{ Převládající vlastnictví kapitálu } \\
\hline Domácí kapitál & 145 & $73,6 \%$ \\
\hline Zahraniční kapitál & 52 & $26,4 \%$ \\
\hline \multicolumn{3}{|l|}{ Využívání nástrojů finančního trhu } \\
\hline Emise akcií & 7 & $3,55 \%$ \\
\hline Emise obligací & 3 & $1,52 \%$ \\
\hline Úvěry & 96 & $48,73 \%$ \\
\hline Nevyužívá a ostatní & 91 & $46,20 \%$ \\
\hline Celkem & 197 & $100,0 \%$ \\
\hline
\end{tabular}

Zdroj: vlastní zpracování 
Dotazování bylo provedeno studenty Ekonomické fakulty TUL pomocí osobního pohovoru s finančními řediteli či finančním oddělením 220 firem z České republiky. Touto metodou se podařilo získat 197 adekvátně vyplněných dotazníků, které byly použity ve vyhodnocení. Dotazování proběhlo v roce 2015. Výběr firem pro dotazníkové šetření závisel na volbě studentů a ochotě firem spolupracovat při vyplnění dotazníku. Vzorek respondentů tedy není možné považovat za reprezentativní a proto i výsledky šetření je nutno brát jako orientační.

Dotazník obsahoval celkem 48 otázek zaměřených na hodnocení výkonnosti podniku z účetního a finančního pohledu, včetně otázek č. 11 až 14 z dotazníku Grahama a Harveye. Neúplně vyplněné dotazníky byly vyřazeny. Vyhodnocení získaných dat bylo provedeno pomocí metod deskriptivní statistiky. V celé práci se pracuje s hladinou významnosti $\alpha=0,05$. Ke stanovení nejvýraznějších determinant kapitálové struktury byla použita metoda faktorové analýzy, což je statistická metoda seskupování dat, která spolu vysoce korelují a redukce počtu původních proměnných na menší počet faktorů (Meloun, Militký 2004).

Vzhledem k názvu metody „faktorová“ analýza, jejímž cílem je stanovení výsledných „faktorư“, je v rámci této studie pro „faktory, které ovlivňují podnik při stanovování optimální výše dluhu v podniku“ a pro „další faktory, které ovlivňují dluhovou politiku v podniku“ používán nadále pojem proměnná. Faktorová analýza „faktorů, které ovlivňují podnik při stanovování optimální výše dluhu v podniku“ původně zahrnovala 14 proměnných, analýza „dalších faktorů, které ovlivňují dluhovou politiku v podniku“ zahrnovala 8 proměnných. Pojem „faktor“ je výstup z faktorové analýzy, který je vytvořen pomocí redukce a sumarizace „proměnných“. Pro zpracování faktorové analýzy byl využit software R.

Dotazník obsahoval i demografické informace o dotazovaných podnicích (tabulka 1). Vzhledem k současnému stavu kapitálového trhu vČeské republice nebyla většina dotazovaných firem veřejně obchodovatelná. Statisticky významně nejčetněji je zastoupena právní forma společnost s ručením omezeným. Zastoupení respondentů dle velikosti podniku je rovnoměrné. U respondentů převažuje vlastnictví domácím kapitálem.

\section{Výsledky výzkumu}

Vyhodnocení dotazníkového šetření bylo provedeno pomocí faktorové analýzy. Faktorová analýza byla provedena odděleně pro proměnné týkající se optimální výše dluhu v podniku a dluhovou politiku podniku. Jednalo se o dvě samostatné otázky s několika proměnnými.

\subsection{Faktorová analýza - stanovování optimální výše dluhu v podniku}

Faktorová analýza významných faktorů ovlivňujících podnik při stanovování optimální výše dluhu byla provedena ve čtyřech krocích (tabulka 2), v rámci nichž byly redukovány proměnné i determinanty. Atributy s hodnotou korelačního koeficientu menšího než $\pm 0,5$ byly vyřazeny. Cílem bylo redukovat proměnné i extrahované faktory na tzv. optimální úroveň, tj. na počet faktorů, které měly největší vliv na výslednou kapitálovou strukturu.

Proměnné a) až n) reprezentují determinanty ovlivňující podnik při stanovování optimální výše dluhu. Respondenti odpovídali na otázku: „Jaké faktory ovlivňují podnik při stanovování optimální výše dluhu ve Vašem podniku?" Významnost jednotlivých faktorů měli ohodnotit pomocí Likertovy škály: 0 - faktor nemá vliv, 4 - faktor má zásadní vliv.

Jednalo se o tyto proměnné ovlivňující podnik při stanovování optimální výše dluhu:

a) využití úrokového daňového štítu,

b) potenciální náklady bankrotu a finanční tísně, 
c) zadluženost jiných firem v našem odvětví,

d) úvěrový rating našeho podniku,

e) transakční náklady a poplatky spojené s dluhovým financováním,

f) výše osobních daní, kterou platí investoři našeho podniku z úroku (např. úrok z dluhopisů),

g) finanční flexibilita (dluh př́liš nevyužíváme, protože máme dostatek vlastních zdrojů na případné nové projekty),

h) nestabilita podnikových zisků a cash flow,

i) omezujeme použití dluhu, aby zákazníci a dodavatelé neměli obavy z možného bankrotu našeho podniku,

j) snažíme se udržovat dostatečně velký objem dluhu, aby náš podnik nebyl atraktivní pro případné př̀evzetí konkurenčním podnikem,

k) když se náš podnik zadluží, naší konkurenci bude zřejmé, že pravděpodobně nebudeme omezovat objem výstupu (výroby),

1) vyšší poměr celkové zadluženosti dává podniku možnost vyjednávat se zaměstnanci o ústupcích z jejich strany,

m) aby si podnik zajistil výkonnost vyššího managementu, zadlužuje se a tím zajistí, že značná část podnikového cash flow je věnována na úhradu úroků z dluhu,

n) podnik omezuje zadlužování, aby zisky z nových (budoucích) projektů plynuly vlastníkům podniku a ne ve formě úroků poskytovatelům dluhu.

Tabulka 2: Faktorová analýza významných faktorů ovlivňujících podnik při stanovování optimální výše dluhu

\begin{tabular}{|c|c|c|c|c|c|}
\hline & 1. krok & 2. krok & 3. krok & 4. krok \\
\hline \multicolumn{2}{|c|}{ Cronbachova alfa } & 0,860 & 0,743 & 0,733 & 0,710 \\
\hline \multicolumn{2}{|c|}{ 95\% konfidenční interval } & $(0,778 ; 0,860)$ & $(0,684 ; 0,803)$ & $(0,671 ; 0,795)$ & $(0,640 ; 0,779)$ \\
\hline \multicolumn{2}{|c|}{ Kaiser-Meyer-Olkinova míra } & 0,827 & 0,774 & 0,754 & 0,713 \\
\hline \multirow{3}{*}{$\begin{array}{l}\text { Bartlettův test } \\
\text { sféricity }\end{array}$} & Chí-kvadrát & 616,7 & 285,42 & 248,33 & 200,7 \\
\hline & $\begin{array}{l}\text { Stupně } \\
\text { volnosti }\end{array}$ & 91 & 28 & 21 & 15 \\
\hline & $\begin{array}{l}\text { Hladina } \\
\text { významnosti }\end{array}$ & 0,0 & 0,0 & 0,0 & 0,0 \\
\hline \multicolumn{2}{|c|}{$\begin{array}{l}\text { Počet proměnných vstupujících } \\
\text { do faktorové analýzy }\end{array}$} & 13 & 8 & 7 & 6 \\
\hline \multicolumn{2}{|l|}{ Počet faktorů } & 6 & 4 & 3 & 2 \\
\hline \multicolumn{2}{|c|}{ Počet proměnných ve faktorech } & 11 & 8 & 6 & 5 \\
\hline \multicolumn{2}{|c|}{ Kumulované procento variability } & 0,529 & 0,557 & 0,490 & 0,510 \\
\hline
\end{tabular}

Zdroj: vlastní zpracování

Cronbachova alfa je splněna ve všech krocích tím, že přesahuje hodnotu 0,7 . Konfidenční interval přestavuje interval, do kterého náhodná veličina spadá s předem zvolenou pravděpodobností 1- $\alpha$. Podmínka dosažení Kaiser-Meyer-Olkinovy míry, tj. hodnoty vyšší než 0,6 , platí ve všech krocích. Bartlettův test sféricky byl splněn ve všech krocích.

V kroku 2 byly vypuštěny proměnné b), f), i) a 1), protože mají statisticky významné zátěže ve faktoru, kde nejsou žádné jiné proměnné. Dále byly vypuštěny proměnné g) a h), protože nemají statisticky významné zátěže $\mathrm{v}$ žádném $\mathrm{z}$ faktorů. $\mathrm{V}$ kroku 3 byla vypuštěna proměnná n), protože má statisticky významné zátěže ve faktoru, kde nejsou žádné jiné proměnné. $\mathrm{V}$ kroku 4 byla vypuštěna proměnná $\mathrm{m}$ ), protože má statisticky významnou zátěž ve faktoru, kde nejsou žádné jiné proměnné. V rámci dalšího kroku by další redukce nebyla př́nosem, žádné další proměnné nebyly vypuštěny a lze tedy identifikovat dva faktory. 
Tabulka 3: Výsledky faktorové analýzy - identifikace významných faktorů ovlivňujících podnik při stanovování optimální výše dluhu

\begin{tabular}{|c|c|c|c|}
\hline Proměnná & F1 & F2 & F3 \\
\hline a) & 0,590 & 0,050 & 0,336 \\
\hline c) & 0,097 & 0,311 & 0,415 \\
\hline d) & 0,597 & 0,287 & 0,144 \\
\hline e) & 0,816 & 0,083 & $-0,049$ \\
\hline j) & 0,115 & 0,605 & 0,388 \\
\hline k) & 0,163 & 0,783 & 0,115 \\
\hline
\end{tabular}

Zdroj: vlastní zpracování

Poznámka: Proměnné a) až n) reprezentuji determinanty ovlivňující podnik při stanovování optimální výše dluhu. Respondenti odpovidali na otázku: „Jaké faktory ovlivňuji podnik při stanovování optimální výše dluhu ve Vašem podniku?" Hodnocení pomoci Likertovy škály: 0-faktor nemá vliv, 4 -faktor má zásadní vliv. Proměnné:

a) využití úrokového daňového štítu,

b) potenciální náklady bankrotu a finanční tísně,

c) zadluženost jiných firem v našem odvětví,

d) úvěrový rating našeho podniku,

e) transakční náklady a poplatky spojené s dluhovým financováním,

f) výše osobnich daní, kterou platí investoři našeho podniku z úroku (např. úrok z dluhopisů),

g) finanční flexibilita (dluh přiliš nevyužíváme, protože máme dostatek vlastních zdrojů na př́padné nové projekty),

h) nestabilita podnikových ziski̊ a cash flow,

i) omezujeme použití dluhu, aby zákazníci a dodavatelé neměli obavy z možného bankrotu našeho podniku,

j) snažíme se udržovat dostatečně velký objem dluhu, aby náš podnik nebyl atraktivni pro př́padné prevzeti konkurenčním podnikem,

k) když se náš podnik zadluží, naši konkurenci bude žrejmé, že pravděpodobně nebudeme omezovat objem výstupu (výroby),

l) vyšši poměr celkové zadluženosti dává podniku možnost vyjednávat se zaměstnanci o ústupcích z jejich strany, m) aby si podnik zajistil výkonnost vyššího managementu, zadlužuje se a tím zajistí, že značná část podnikového cash flow je věnována na úhradu úrokủ z dluhu,

n) podnik omezuje zadlužování, aby zisky z nových (budoucích) projektů plynuly vlastníkům podniku a ne ve formé úroků poskytovatelüm dluhu.

Faktorovou analýzou proměnných ovlivňující podnik při stanovování optimální výše dluhu byly získány dva faktory (tabulka 3). Jednotlivé faktory jsou tvořeny rozdílným počtem proměnných (vyznačeny podbarvením).

Faktor 1 zahrnuje ,a) využití úrokového daňového štítu“, „,d) úvěrový rating našeho podniku“ a „e) transakční náklady a poplatky spojené s dluhovým financováním“, byl tedy souhrnně nazván finanční aspekty dluhového financování.

Faktor 2 je dán proměnnými ,j) snažíme se udržovat dostatečně velký objem dluhu, aby náš podnik nebyl atraktivní pro případné převzetí konkurenčním podnikem“ a „k) když se náš podnik zadluží, naší konkurenci bude zřejmé, že pravděpodobně nebudeme omezovat objem výstupu (výroby)“ se souhrnným názvem dluh jako nástroj dalšího rozvoje podniku.

Tabulka 4: Důležitost proměnných ovlivňujících podnik při stanovování optimální výše dluhu - variabilita faktorů

\begin{tabular}{|l|c|c|c|}
\hline & F1 & F2 & F3 \\
\hline Vlastní hodnota & $\mathbf{1 , 4 1 9}$ & $\mathbf{1 , 1 6 8}$ & 0,472 \\
\hline Procento variability & $\mathbf{0 , 2 3 6}$ & $\mathbf{0 , 1 9 5}$ & 0,079 \\
\hline Kumulované \% variability & $\mathbf{0 , 2 3 6}$ & $\mathbf{0 , 4 3 1}$ & 0,510 \\
\hline
\end{tabular}

Zdroj: vlastní zpracování 
Dle tabulky 4 je kumulovaná variabilita 43,1 \%, z níž faktor 1 „finanční aspekty dluhového financování“ tvoří 23,6 \% a faktor 2 „dluh jako nástroj dalšího rozvoje podniku“ 19,5 \%. Je tedy zřejmé, že faktor 1 je respondenty vnímán jako dominantní při stanovování optimální výše dluhu v podniku, což je logické ve vztahu k získávání cizích zdrojů financování (a s tím spojenými náklady) a využívání efektu daňového štítu. Rovněž faktoru 2 je respondenty přisuzován poměrně značný vliv. Tento faktor obhajuje využívání cizích zdrojů v podniku jako nástroje pro další fungování a rozvoj podniku, kdy podnik získá dostatečné zdroje pro své výstupy a zároveň nebude atraktivní pro nepřátelské př̀evzetí konkurenčními podniky.

\subsection{Faktorová analýza - dluhová politika podniku}

Faktorová analýza významných faktorů ovlivňujících dluhovou politiku podniku byla provedena $\mathrm{v}$ jednom kroku (tabulka 5), ve kterém se podařilo identifikovat jeden faktor.

Proměnné a) až h) reprezentují další faktory ovlivňující dluhovou politiku podniku. Respondenti odpovídali na otázku: „Jaké další faktory ovlivňují dluhovou politiku Vašeho podniku?" Hodnocení proběhlo rovněž pomocí Likertovy škály: 0 - faktor nemá vliv, 4 - faktor má zásadní vliv.

Jednalo se o tyto proměnné, představující další faktory ovlivňující dluhovou politiku podniku: a) podnik používá dluh pouze $\mathrm{v}$ prrípadě nedostatku vlastních zdrojů a zisku, b)dluhové financování (např. pomocí obligací) dělá lepší dojem na investory než emise nových akcií,

c) podnik se zadlužuje, když jsou úrokové sazby na mimořádně nízké úrovni,

d) podnik používá dluh, když je vlastní kapitál podniku na trhu podhodnocen,

e) zpravidla odkládáme použití dluhu z důvodu transakčních nákladů a poplatků,

f) odkládáme splacení dluhu z důvodu rekapitalizačních nákladů a poplatků,

g) změny tržní ceny akcií podniku,

h) podnik se zadlužuje ve chvíli, když dosáhl dostatečných zisků.

Tabulka 5: Faktorová analýza významných faktorů ovlivňujících dluhovou politiku podniku

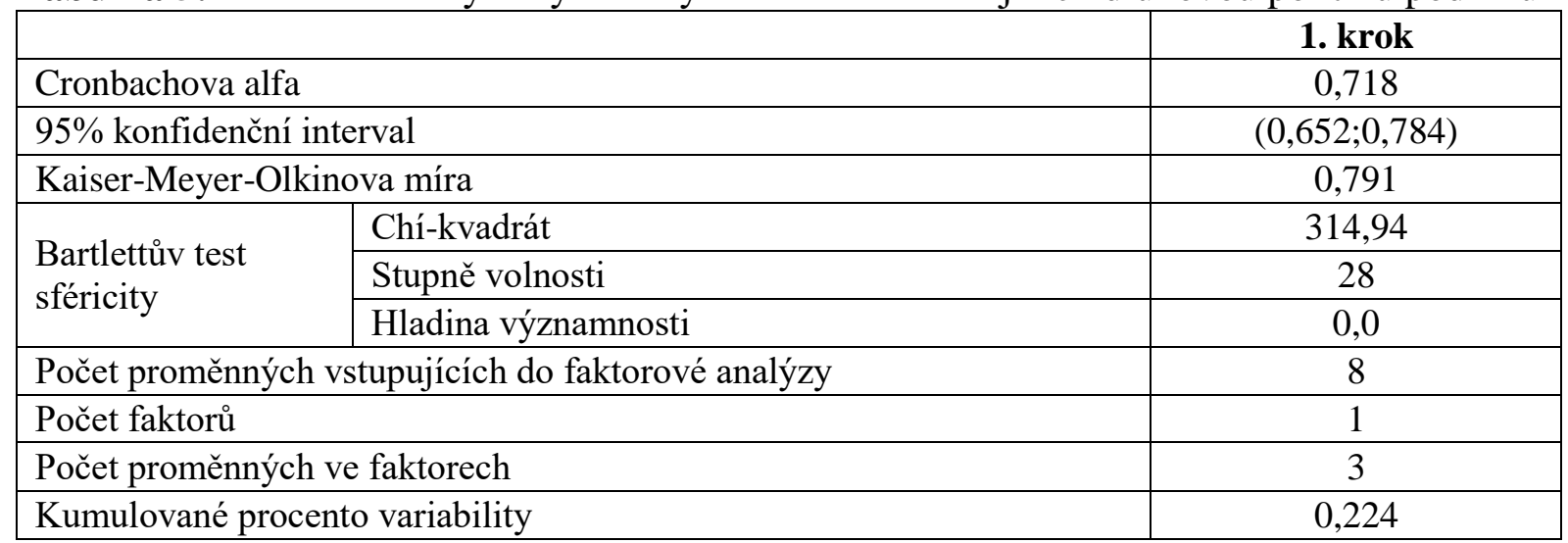

Zdroj: vlastní zpracování 
Tabulka 6: Výsledky faktorové analýzy - identifikace významných faktorů ovlivňujících dluhovou politiku podniku

\begin{tabular}{|c|c|c|c|c|}
\hline Proměnná & F1 & F2 & F3 & F4 \\
\hline a) & $-0,014$ & 0,415 & 0,142 & $-0,071$ \\
\hline b) & 0,507 & 0,139 & $-0,015$ & 0,142 \\
\hline c) & 0,206 & 0,352 & 0,838 & 0,354 \\
\hline d) & 0,720 & 0,203 & 0,211 & 0,121 \\
\hline e) & 0,391 & 0,774 & 0,037 & 0,213 \\
\hline f) & 0,369 & 0,278 & 0,076 & 0,419 \\
\hline g) & 0,789 & $-0,071$ & 0,130 & 0,281 \\
\hline h) & 0,169 & $-0,059$ & 0,157 & 0,475 \\
\hline
\end{tabular}

Zdroj: vlastní zpracování

Poznámka: Proměnné a) až h) reprezentují dalši faktory ovlivňující dluhovou politiku podniku. Respondenti odpovidali na otázku: „,Jaké dalši faktory ovlivňuji dluhovou politiku Vašeho podniku?“”

Hodnoceni pomoci Likertovy škály: 0-faktor nemá vliv, 4-faktor má zásadní vliv.

Proměnné:

a) podnik použivá dluh pouze v prípadě nedostatku vlastních zdrojů a zisku,

b) dluhové financování (např. pomocí obligací) dělá lepši dojem na investory než emise nových akcií,

c) podnik se zadlužuje, když jsou úrokové sazby na mimořádně nízké úrovni,

d) podnik používá dluh, když je vlastni kapitál podniku na trhu podhodnocen,

e) zpravidla odkládáme použití dluhu z di̊vodu transakčních nákladi̊ a poplatků,

f) odkládáme splacení dluhu z di̊vodu rekapitalizačních nákladi̊ a poplatků,

g) zmény tržní ceny akcií podniku,

h) podnik se zadlužuje ve chvíli, když dosáhl dostatečných zisků.

V prvním kroku byly vypuštěny proměnné a), f) a h), protože nemají statisticky významné zátěže v žádných faktorech. Dále pak proměnné c) a e), protože mají statisticky významnou zátěž ve faktoru, kde nejsou žádné jiné proměnné. Tím pádem dochází k redukci počtu proměnných pod minimum pro faktorovou analýzu. Lze konstatovat, že se podařilo již v prvním kroku identifikovat jeden faktor, zahrnující proměnné b), d) a g). Tento faktor je tvořen třemi proměnnými (vyznačeny podbarvením) (tabulka 6).

Identifikovaný faktor tvoří proměnné „b) dluhové financování (např. pomocí obligací) dělá lepší dojem na investory než emise nových akcií“, „d) podnik používá dluh, když je vlastní kapitál podniku na trhu podhodnocen“ a ,g) změny tržní ceny akcií podniku (v prrípadě veřejné obchodovatelnosti)“, souhrnně byl nazván specifika dluhového a kapitálového trhu.

Tabulka 7: Důležitost proměnných ovlivňujících dluhovou politiku podniku - variabilita faktorů

\begin{tabular}{|l|c|c|c|c|}
\hline & F1 & F2 & F3 & F4 \\
\hline Vlastní hodnota & $\mathbf{2 , 4 5 9}$ & 1,962 & 1,787 & 1,118 \\
\hline Procento variability & $\mathbf{0 , 2 2 4}$ & 0,178 & 0,162 & 0,102 \\
\hline Kumulované \% variability & $\mathbf{0 , 2 2 4}$ & 0,402 & 0,564 & 0,666 \\
\hline
\end{tabular}

Zdroj: vlastní zpracování

Všechny proměnné zahrnuté do tohoto faktoru mají úzký vztah k finančnímu a kapitálovému trhu. Dluhová politika podniku je ovlivněna vzájemnou interakcí podniku a finančního trhu, kdy respondenti připouští použití dluhového financování jako formy signalizování pro investory. Dále zvažují využití dluhu, když je vlastní kapitál na trhu podhodnocen a když dochází ke změnám tržní ceny akcií podniku. 


\subsection{Vyhodnocení dotazníkového šetření}

Primární funkcí faktorové analýzy je redukce proměnných, kterou lze provést pouze za podmínky vzájemných závislostí proměnných a za předpokladu, že tyto závislosti jsou důsledkem působení určitého menšího počtu v pozadí stojících neměřitelných veličin. Tyto veličiny jsou označovány jako faktory. Faktorová analýza byla provedena na základě výsledků empirického dotazování ve dvou oblastech: jedna část dotazníku byla zaměřena na faktory ovlivňující podnik při stanovování optimální výše dluhu v podniku a druhá část na další faktory, které ovlivňují dluhovou politiku podniku.

První část faktorové analýzy zaměřená na faktory ovlivňující podnik při stanovování optimální výše dluhu v podniku odhalila dva faktory. Faktor 1 zahrnuje proměnné „využití úrokového daňového štítu“, „úvěrový rating našeho podniku“ a „transakční náklady a poplatky spojené s dluhovým financováním“. Souhrnně byl tento faktor nazván „finanční aspekty dluhového financování“. Využití úrokového daňového štítu, který do určité míry zadlužení snižuje průměrné náklady kapitálu, patří k základním předpokladům kompromisní teorie kapitálové struktury. Ta chápe volbu kapitálové struktury podniku jako kompromis mezi úrokovým daňovým štítem a náklady finanční tísně, které naopak průměrné náklady kapitálu zvyšují. Náklady finanční tísně představují náklady, které souvisejí s dluhovým financováním. S růstem zadlužení podniku roste i finanční riziko a tím rostou i náklady $\mathrm{s}$ dluhovým financováním související. To odpovídá i závěrům tradicionalistické teorie, která se opírá o „U“ křivku průměrných nákladů kapitálu. Lze tedy konstatovat, že identifikace faktoru finanční aspekty dluhového financování přispívá k potvrzení platnosti kompromisní teorie kapitálové struktury.

Faktor 2 je dán proměnnými „snažíme se udržovat dostatečně velký objem dluhu, aby náš podnik nebyl atraktivní pro případné převzetí konkurenčním podnikem“ a „když se náš podnik zadluží, naší konkurenci bude zřejmé, že pravděpodobně nebudeme omezovat objem výstupu (výroby)“. Souhrnně byl nazván „dluh jako nástroj dalšího rozvoje podniku“. Proměnné tvořící tento faktor odpovídají závěrům teorie signalizování, která je založená na existující informační asymetrii mezi manažery a investory. Předpokladem je, že manažeři mají všechny potřebné informace o hospodaření společnosti, zatímco externí investoři musí spoléhat pouze na zveřejňované informace. Zvyšování zadluženosti by tedy pro investory mělo být signálem dobré ekonomické situace podniku.

Druhá část faktorové analýzy byla zaměřena na další faktory, které ovlivňují dluhovou politiku podniku, pomocí níž se podařilo identifikovat jeden faktor nazvaný „,specifika dluhového a kapitálového trhu“. Faktor zahrnuje proměnné „dluhové financování (např. pomocí obligací) dělá lepší dojem na investory než emise nových akcií“, „,podnik používá dluh, když je vlastní kapitál podniku na trhu podhodnocen“ a „změny tržní ceny akcií podniku“. Na kapitálovém trhu je prostřednictvím tržní ceny akcií determinována tržní hodnota podniku, míra výnosnosti požadovaná investory u jednotlivých cenných papírů kvantifikuje riziko spojené s podnikatelskými aktivitami, akciový trh lze navíc považovat za spolehlivý indikátor hospodářského vývoje (Nývltová 2007). Česká republika tradičně patří do skupiny ekonomik se závislostí na bankovním sektoru, což je jeden z důvodů pro nízkou likviditu kapitálové trhu v české ekonomice. Antoniou (2008) udává signifikantní rozdíly v tvorbě kapitálové struktury mezi zeměmi orientovanými na kapitálový trh a zeměmi orientovanými na banky. Mezi tyto faktory zahrnuje rozdíly v legislativních podmínkách zemí, finanční struktuře, účetních a daňových systémech, podnikovém řízení, apod. Identifikace faktoru specifika dluhového a kapitálového trhu na základě uvedených proměnných tedy může působit $\mathrm{v}$ českém prostředí trochu překvapivě, vzhledem $\mathrm{k}$ faktu, že 
pouze minimum podniků v České republice využívá nástroje kapitálového trhu ke svému financování. Každopádně faktor vysvětluje postoje českých finančních manažerů, kteří již zřejmě vnímají kapitálové trhy jako samozřejmou součást finančního trhu a místo pro získávání dodatečných zdrojů financování.

\section{Závěr}

Cílem př́spěvku bylo identifikovat dominantní faktory determinující kapitálovou strukturu firem v České republice. Identifikace faktorů byla provedena na základě empirického dotazování, kjehož vyhodnocení byly využity pokročilejší modely statistické analýzy (faktorová analýza). Základní funkcí faktorové analýzy je redukce počtu proměnných, kterou lze provést za podmínky vzájemných závislostí proměnných a za předpokladu, že tyto závislosti jsou důsledkem působení určitého menšího počtu v pozadí stojících neměřitelných veličin. Tyto veličiny jsou označovány jako faktory.

Pomocí faktorové analýzy se podařilo identifikovat tři souhrnné faktory. Faktor 1 zahrnuje proměnné ,využití úrokového daňového štítu“, „úvěrový rating našeho podniku“ a „transakční náklady a poplatky spojené s dluhovým financováním“, souhrnně byl nazván „finanční aspekty dluhového financování“. Identifikace tohoto faktoru odpovídá závěrům kompromisní teorie kapitálové struktury. Faktor 2 je dán proměnnými „,snažíme se udržovat dostatečně velký objem dluhu, aby náš podnik nebyl atraktivní pro případné převzetí konkurenčním podnikem“ a „když se náš podnik zadluží, naší konkurenci bude zřejmé, že pravděpodobně nebudeme omezovat objem výstupu (výroby)“. Souhrnně byl nazván „dluh jako nástroj dalšího rozvoje podniku“. Proměnné tvořící tento faktor odpovídají závěrům teorie signalizování, dle níž zvyšování zadluženosti může být signálem dobré ekonomické situace podniku. Faktor 3 nazvaný ,specifika dluhového a kapitálového trhu“ zahrnuje proměnné „dluhové financování dělá lepší dojem na investory než emise nových akcií“, „podnik používá dluh, když je vlastní kapitál podniku na trhu podhodnocen“ a „změny tržní ceny akcií podniku“. Identifikace tohoto faktoru je překvapivým závěrem analýzy, vzhledem k faktu, že pouze minimum podniků v České republice využívá nástroje kapitálového trhu ke svému financování. Každopádně faktor vysvětluje postoje českých finančních manažerů, kteří začínají vnímat kapitálové trhy jako samozřejmou součást finančního trhu a místo pro získávání dodatečných zdrojů financování.

Hlavní prínos tohoto článku lze spatřovat $\mathrm{v}$ jeho př́nosu v oblasti teoretického zkoumání kapitálové struktury podniků v České republice. Nicméně výsledky dotazování je třeba interpretovat s jistou mírou opatrnosti, vzhledem k potenciálnímu zkreslení a chybám měření, které jsou obvykle spojeny $\mathrm{s}$ údaji $\mathrm{z}$ empirického průzkumu. Průzkumy měří názory respondentů a nemusí představovat reálnou skutečnost. Zároveň mohou být výsledky provedených analýz do značné míry ovlivněny charakterem a složením výběrového souboru.

Na základě výsledků provedených analýz je možné stanovit určitá doporučení, vztahující se k dalšímu zkoumání problematiky determinant kapitálové struktury firem. Jedná se především o metodická doporučení týkající se stanovení výběrového souboru respondentů tak, aby daný vzorek byl reprezentativní a závěry analýz bylo možné zobecnit na základní soubor. Dále by bylo vhodné provést jednotlivé faktorové analýzy zvlášt' pro jednotlivá odvětví, protože vztah mezi odvětvovou zadlužeností a kapitálovou strukturou byl potvrzen řadou empirických studií.

Jedinečnost této studie spočívá v inovativním využití faktorové analýzy pro identifikaci faktorů determinujících kapitálovou strukturu firem v České republice. Tato statistická 
metoda byla doposud využívána převážně v psychologii, sociologii či marketingu. Jako proměnné byly zvoleny determinanty, použité v dotazníku vytvořeného Grahamem a Harveyem (2001). Odpovědi na shodné otázky byly statisticky testovány a mezinárodně srovnávány $\mathrm{v}$ řadě dalších empirických studií z různých zemí světa.

\section{Literatura}

[1] ANTONIOU, A., et al, 2008. The Determinants of Capital Structure: Capital MarketOriented versus Bank-Oriented Institutions. Journal of Financial and Quantitative Analysis, 43(1), 1-41. ISSN 0022-1090.

[2] AUlOVÁ, R. and T. HLAVSA, 2013. Capital Structure of Agricultural Businesses and its Determinants. Agris on-line Papers in Economics and Informatics, 5(2), 23-36. ISSN 1804-1930.

[3] BAKER, H. and G. S. MARTIN, 2011. Capital structure: theory, evidence, and practice. Hoboken, N. J.: Wiley. ISBN 978-047-0569-528.

[4] BANCEL, F. and U. R. MITTOO, 2004. Cross-Country Determinants of Capital Structure Choice: A Survey of European Firms. Financial Management, 33(4), 103-132.

[5] BENETTI, C., R. DECOURT and P. TERRA, 2007. The practice of corporate finance in Brazil and in the USA: comparative survey evidence. Anais: VII Encontro Brasileiro de Finanças. São Paulo.

[6] BENETTI, C., R. DECOURT and P. TERRA, 2007. The practice of corporate finance in an emerging market: preliminary evidence from the Brazilian survey. Annual Meeting of the Financial Management Association.

[7] BROUNEN, D., A. de JONG and K. KOEDIJK, 2006. Capital structure policies in Europe: Survey evidence. Journal of Banking, 30(5), 1409-1442.

[8] DVOř́́K, V., 2004. Financing of Companies in the Czech Republic (Empirical Study), In: M. Mejstř́k, ed. Cultivation of Financial Markets in the Czech Republic. Praha: Karolinum. ISBN 80-246-0980-0.

[9] GRAHAM, J. R. and C. R. HARVEY, 2001. The theory and practice of corporate finance: evidence from the field. Journal of Financial Economics, 60(2-3), 187-243. ISSN 0304-405X.

[10] KISLINGEROVÁ, E., 2010. Manažerské finance. Praha: C. H. Beck. ISBN 978-807400-194-9.

[11] KRAUSEOVÁ, J., 1995. Analýza kapitálové struktury českých firem. Finance a úvěr, 45(9), 481-491. ISSN 0015-1920.

[12] MELOUN, M. a J. MILITKÝ, 2004. Statistická analýza experimentálních dat. Praha: Academia. ISBN 80-200-1254-0.

[13] MILLER, M. H. and K. ROCK, 1985. Dividend Policy under Asymmetric Information. The Journal of Finance, 40(4), 1031-1051. ISSN 0022-1082.

[14] NEUMAIEROVÁ, I. a I. NEUMAIER, 1996. Úvaha o optimální zadluženosti. Finance a úvěr, 46(1), 51-61. ISSN 0015-1920.

[15] NÝVLTOVÁ, R., 2007. Mezinárodni kapitálové trhy: zdroj financování. Praha: Grada. ISBN 978-80-247-1922-1. 
[16] PRÁS̆ILOVÁ, P., 2012. Determinanty kapitálové struktury českých podniků. $E+M$ Ekonomie a Management, 15(1), 89-104. ISSN 1212-3609.

[17] R CORE TEAM, R, 2012. A language and environment for statistical computing [online]. R Foundation for Statistical Computing, Vienna. ISBN 3-900051-07-0, Dostupné z: www.R-project.org

[18] ROSS, S. A., 1977. The Determination of Financial Structure: The Incentive-Signalling Approach. The Bell Journal of Economics [online]. 8(1), 23-40. Dostupné z: www.jstor.org/stable/3003485

[19] RŮČKOVÁ, P., 2015. Vliv likvidity a rentability na využití zdrojů financování ve zpracovatelských podnicích v zemích V4. Acta academica karviniensia, XV(3), 69-79. ISSN 1212-415X.

[20] TITMAN, S. and R. WESSELS, 1988. The Determinants of Capital Structure Choice. The Journal of Finance, 43(1), 1-19. DOI: 10.1111/j.1540-6261.1988.tb02585.x 